\title{
WHY DON'T YOU COME OVER? - A DIFFERENT WAY TO PROMOTE ROMANIA
}

\author{
Monica Pătruț \\ "Vasile Alecsandri” University of Bacău \\ monicapatrut@yahoo.com
}

\begin{abstract}
Investing in the country brand represents a strategic priority as it consolidates the image and international reputation of the respective members. Although Romania started to invest in this long-term process in 1996, the promotional actions have lacked coordination and efficiency. The Romania's country image is insufficiently shaped and the Country Brand Index study conducted in 2012 confirms it by placing our country on the last positions. We shall show in this study that by exploiting the collective intelligence principle and the involvement of the Net Generation's representatives, many echoing campaigns can be created in the virtual environment. The country brand is being built rather by means of every individual's involvement, by what we do and what we say every day. "Why Don't You Come Over?" campaign, which has contributed in an unexpected way to improve Romania's image by spreading humor in the virtual space, should show all actors responsible that there may be successful promotion patterns.
\end{abstract}

\section{Keywords}

promotion campaign; country brand; user-generated content; Romania; Gândul newspaper (The Thought)

\section{JEL Classification}

M37

\section{An inefficient promotion ...for an ever surprising Romania}

A country image reflects the manner in which we perceive that country as a tourist destination, as well as a place for investment or as a source of origin of goods. As Van Ham noted (2001), a bad or lack of a reputation represents a serious handicap for a country who has been trying to remain competitive in the international arena. The image and reputation therefore become essential components of a strategic arsenal of a state.

We shall start this article by making a summary of Romania's efforts to create and promote its own country image. This concept occupies a central position in the area of international public relations, the specialists in this field having agreed that a positive national image is a benefit which leads to attracting foreign investment, developing tourism and cordial relations with other countries (Curtin \& Gaither, 2008). Following this pattern, as it can be seen in table 1 , Romania has promoted at random various different components which contribute to the creation of a country image: tourism, Brancusi, Eminescu, "Made in Romania” products, George Enescu Music Festival and various trade fairs. Each of the institutions involved has promoted its activities by itself, on the conventional media channels, and Romania's image campaigns lacked the most basic coordination (Nicolescu, 2008) and that they were far from being effective in the creation and strengthening of the country brand. 
Table 1 The best-known promotion campaigns initiated by institutions in Romania

\begin{tabular}{|c|c|c|c|}
\hline Year & Name of the campaign/product & Domain & Initiators \\
\hline 1996 & $\begin{array}{l}\text { Eterna şi fascinanta Românie } \\
\text { (Eternal and fascinating Romania) }\end{array}$ & tourism & Romanian Government \\
\hline 2001 & $\begin{array}{l}\text { România, mereu surprinzătoare } \\
\text { (Romania, ever surprising) }\end{array}$ & tourism & Ogily \& Mathers Romania. \\
\hline 2004 & $\begin{array}{l}\text { România, o destinaţie atractivă } \\
\text { pentru investiţiile străine } \\
\text { (Romania, an attractive destination } \\
\text { for foreign investments) }\end{array}$ & $\begin{array}{l}\text { foreign } \\
\text { investments }\end{array}$ & $\begin{array}{l}\text { Romanian Agency for Foreign } \\
\text { Investments }\end{array}$ \\
\hline 2005 & $\begin{array}{l}\text { Imaginează-ţi România! } \\
\text { (Fancy Romania!) }\end{array}$ & tourism & $\begin{array}{l}\text { Group of initiative to promote } \\
\text { Romania's country image }\end{array}$ \\
\hline 2005 & $\begin{array}{l}\text { Romanian Cultural Institute } \\
\text { (Institutul Cultural Român) }\end{array}$ & $\begin{array}{l}\text { External } \\
\text { politics }\end{array}$ & Ministry of External Affairs \\
\hline 2005 & $\begin{array}{l}\text { Deceniul cultural roman (Romanian } \\
\text { cultural decade) }\end{array}$ & $\begin{array}{l}\text { External } \\
\text { politics }\end{array}$ & Ministry of External Affairs \\
\hline 2006 & Romania, fabulous spirit & & Ministry of External Affairs \\
\hline 2006 & $\begin{array}{l}\text { Mari români } \\
\text { (Famous Romanians) }\end{array}$ & cultural & Romanian Television \\
\hline 2007 & Made in Romania & products & $\begin{array}{l}\text { Romanian Dairy Industry } \\
\text { Association , Romanian Meat } \\
\text { Association and National } \\
\text { Vineyard Growers and Wine } \\
\text { Producers , Violet Advertising }\end{array}$ \\
\hline 2007 & $\begin{array}{l}\text { Fabricat în România } \\
\text { (Made in Romania) }\end{array}$ & products & $\begin{array}{l}\text { Chamber of Commerce of } \\
\text { Romania }\end{array}$ \\
\hline 2007 & Romania, Your Business Partner & $\begin{array}{l}\text { foreign } \\
\text { investments }\end{array}$ & $\begin{array}{l}\text { Romanian Agency for Foreign } \\
\text { Investments }\end{array}$ \\
\hline 2008 & $\begin{array}{l}\text { Hola, soy rumano! } \\
\text { (Hello, I'm a Romanian.) }\end{array}$ & $\begin{array}{l}\text { Repairing } \\
\text { country's } \\
\text { image }\end{array}$ & $\begin{array}{l}\text { Agency for Governmental } \\
\text { Strategies }\end{array}$ \\
\hline 2008 & $\begin{array}{l}\text { România. Piacere di conoscerti } \\
\text { (Romania, nice to meet you / always } \\
\text { a pleasure to know you) }\end{array}$ & $\begin{array}{l}\text { Repairing } \\
\text { country's } \\
\text { image }\end{array}$ & $\begin{array}{l}\text { Agency for Governmental } \\
\text { Strategies }\end{array}$ \\
\hline 2009 & Romania -The Land of Choice & tourism & Ministry of Tourism \\
\hline 2010 & Explore the Carpathian Garden & tourism & Ministry of Tourism \\
\hline
\end{tabular}

Source: author's data

Specialists in the field of public relations (Dolea \& Ţăruş, 2009) are drawing an alarm signal, warning that it is not enough to find out that Romania is unfavorably associated with Dracula, Ceausescu, stray dogs, pickpockets, street children, rromi and communism. It is not enough to accuse and say that Romania has got a negative or shapeless country image. "A country is a complex 'product' and the process of assigning a coherent meaning to this product is multilateral and it is difficult to achieve” (Dolea \& Ţărus, 2009).

Romania's efforts for discovering and promoting its own image in the world should be continued and organized much better.

As illustrated in the study entitled Country Brand Index (2012), carried out on a sample of 118 countries, the results obtained so far have been almost insignificant, our country being placed only on the 100th place. State institutions and citizens should understand that a successful brand is considered to be "an essential national 
wealth" (Olins, 2006) and for reaching it, "it takes more than a slogan, some colours and a distinctive logo" (Olins, 2006).

\section{Web 2.0. - A better environment for promoting the country brand}

Slowly, but surely, brands have learned to use the power of the Internet for their advantage. Facilitating the distribution of information and the connection between the people, on the one hand, and offering speed and a huge capacity for the distribution of messages, on the other hand, the Internet is the most hospitable host which allows consumers and brands to have a dialogue on equal terms. Web 2.0 technologies allow internet-consumers to generate content, chat online and build different types of relations. Online interactions with consumers may have different intensities, starting with information and interaction and ending with relationships and involvement (Fisher-Buttinger, Vallaster, 2011). Exploiting the collective intelligence principle and the Internauts' desires to collaborate and to stay connected all the time (Leadbeater, 2010), brands may also interact with virtual communities formed by expert users and information multipliers or opinion leaders. The interaction models considered to be successful are the following: entertainment hunters for viral campaigns, virtual worlds and webisodes, creative contributors to the realisation of assessment portals, reviews and tops, collaborative editing, inventive experts for product improvement and innovation or their testing and, lastly, open-source collaborators which plan, manage, and complete projects launched by the companies (crowdsourcing). (Fisher-Buttinger, Vallaster, 2011).

This revolution of virtual participation and collaboration has given rise to the phenomenon wikinomics (Tapscott and Williams, 2010), phenomenon which, by means of participating production, promises to exploit human abilities, ingenuity and intelligence much quicker and more efficient than they have been exploited so far over the course of the history.

The Romanians' wish to get actively involved in creating the country brand and not to assist passively at the failed attempts of the government or mass-media is highlighted by the study entitled Romanians' perception on Romania's country image (2013).

Starting from a questionnaire with 23 questions which was promoted in the online environment and applied on a sample consisting of 223 persons, 47\% of them being bloggers, the participants in the study underlined the fact that beyond the governmental strategies and the more or less successful media campaigns, the country brand is being built rather by means of every individual's involvement, by what we do and what we say every day (see figure 1).

Brand strategies have not given the expected results yet. For the European citizens, Romania's main characteristics are largely the same: a poor and corrupt country, a country in which fraud, theft and high criminality are often met a country with a communist background, an unsafe and possibly dangerous country. There are also found old traditions and customs, special landscapes and beautiful forests, poor children and orphans who live on the street or in orphanages. Participants in this study emphasize the imperativeness with which Romania has to create a unique and competitive identity and shows the availability of the young people involved in the online environment to contribute to creating the country brand.

\section{A virtual success story: Why Don't You Come Over? Trigger factor}

The unfavorable image of Romania is also due largely to the negative actions of some of the Romanians who went to work abroad and an ongoing influence in this 
direction by the international press against the lack of firm reactions from the Romanian authorities. The most famous case over the last year is the one caused by the British government's intention to launch a campaign to discourage Romanians and Bulgarians to come to the UK starting from 1 January 2014, after clearing restrictions on the labor market.

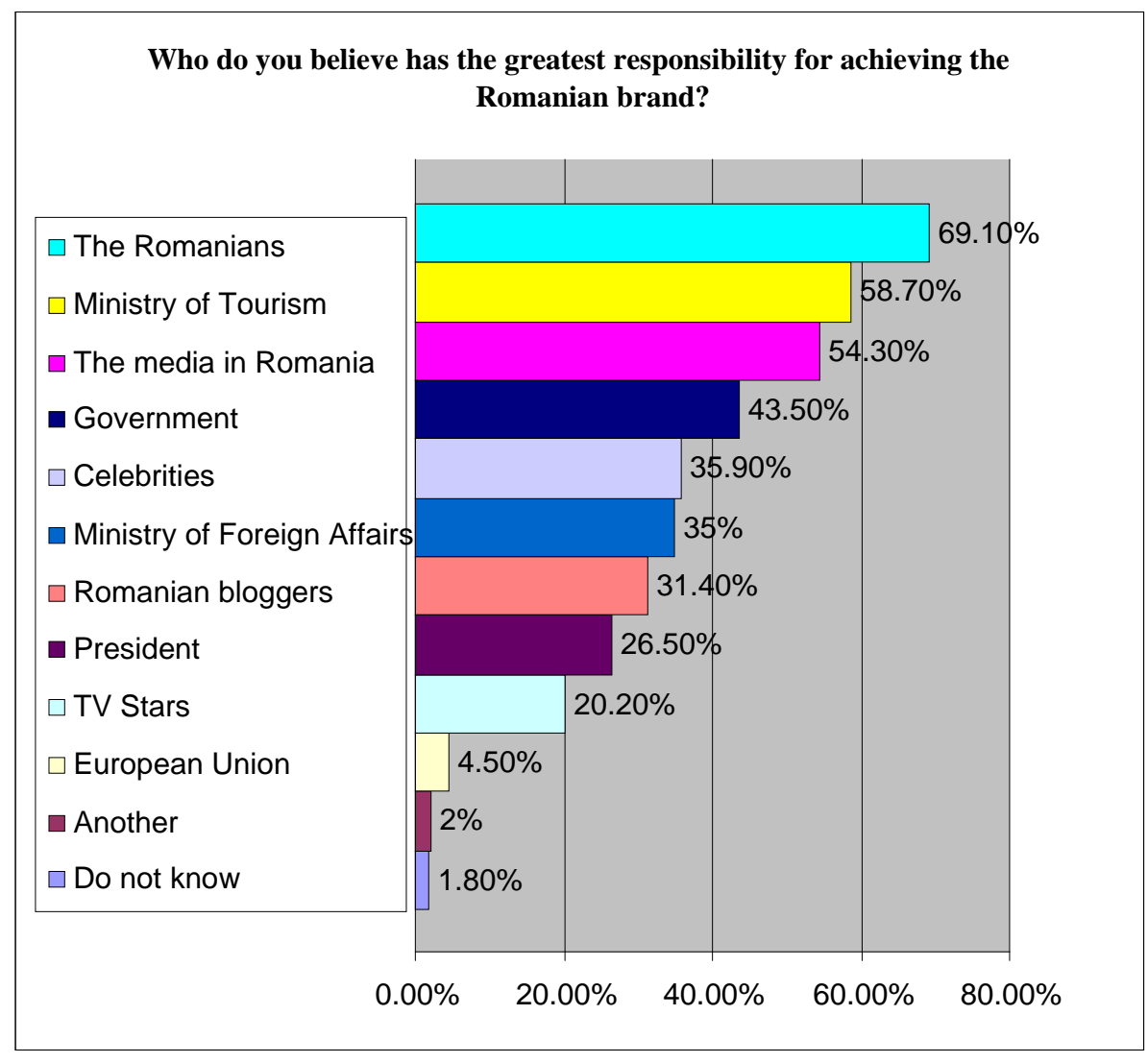

Figure 1 Answers for the question about the greatest responsibility for achieving the Romanian brand

Source: http://brandstorming.blogalinitiative.ro/studiu-de-caz/ce-cred-romanii-despre-romania

The British newspaper, The Guardian, has started a campaign, Don't come to Britain!, to discourage possible Romanians and Bulgarians emigrants who could come to work in the United Kingdom by using stereotypes, such as Romanians and Bulgarians are "pickpockets, scam artists and scroungers". Although the Romanian and Bulgarian Europarliament members have sent a letter to the president of the European Commission, Jose Manuel Barroso, blaming the British government's intention to launch a campaign to discourage the Romanians and Bulgarians to come in the UK, on 27 January 2013, the British newspaper invited readers to join this campaign and create slogans and posters to discourage immigration (see a selection of them in figure 2).

The well-known messages of the British campaign have been the following:

- "Don’t come to Britain! It’s full ....of alcopops, asbestos, bad housing, bishops, the British, chavs, Closer magazine, corrupt politicians, cuts, the Daily Mail, dodgy 
scientists, dogging, drugs with stupid names, drunks, dying bees, dying trees etc. We hate ourselves - we'll probably hate you too."

- "Great (used to be) Britain. The biggest dump. Go to Australia Instead!"

- "The sky in UK is this color for 8 months a year. Try Miami instead!"

- "Grey Britain is a stinky, wet, racist tramp. France is even worse. But they have better/cheaper booze."

-"Come here and clean the loo. Britain is full of horrible jobs we employ foreigners to do. You're welcome!”

- "Great Britain. Land of opportunities. Restrictions apply.”

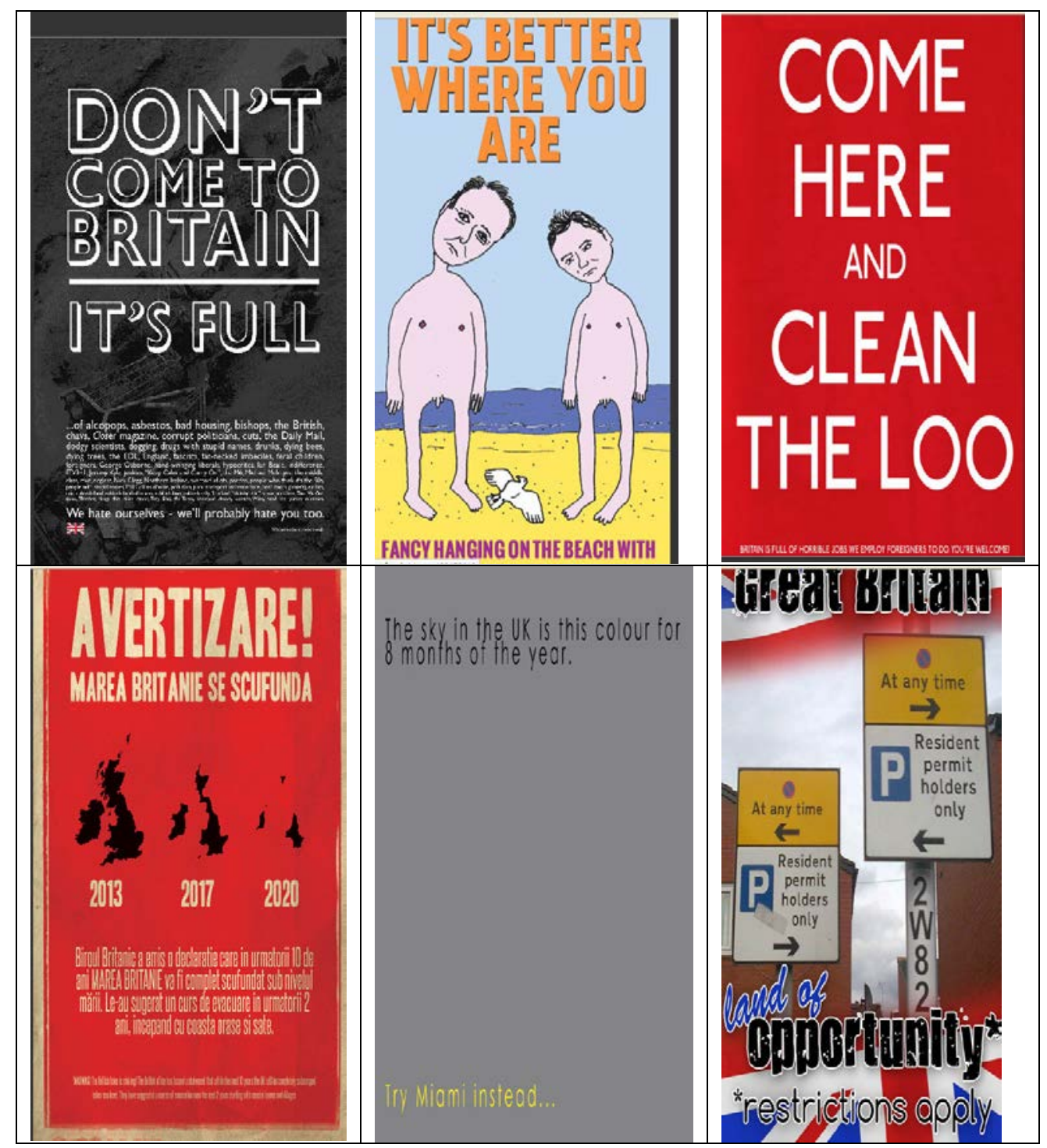

Figure 2 British slogans and posters to discourage immigration

Source: http://www.theguardian.com/uk/gallery/2013/jan/29/immigration-britain-ministersgallery $\# /$ ?picture $=403153052 \&$ index $=0$ 
- "It's better where you are. Fancy hanging on the beach with David Cameron and observing dead seagulls? Neither do we. Britain is shit“.

The suggestions sent to the daily newspaper The Guardian by its readers for the antiimmigration campaign, which the UK Government thought about, have stressed the unpleasant country-specific conditions and have gradually turned into an irony at the United Kingdom and at the politicians who, without studying any official sources, resorted to alarming speeches which promoted figures of hundreds of thousands of Romanian immigrants to invade the United Kingdom on 1 January 2014, a fact denied by the reality.

\section{... And a prompt, really funny and effective reaction}

On 30 January 2013, in response to the campaign initiated by The Guardian, the Gândul newspaper and GMP Advertising launched the campaign Why Don't You Come Over? by means of which they invited the British to come to Romania. Designed as a campaign to change attitudes (Newsom, Turk \& Kruckeberg , 2003), Why Don't You Come Over? Campaign intended to improve Romania's image by presenting the real situation in our country and discourage discrimination of Romanians caused by promoting stereotypes in the British tabloids. Mihai Gongu, manager of the GMP Advertising (Michael, 2013), shows the situation as a "fight" between the British readers of The Guardian and the Romanians who read the Gândul newspaper. While the former are invited to submit reasons why living in UK is not nice, Romanians have to find arguments to support that living in Romania is wonderful, giving the British reasons to come here. In order to involve the Internet readers in this campaign, those from the Gândul newspaper have launched a Facebook application where users can produce their own print. After typing a message of no more than 65 characters, the application automatically generates a print and posts on the Facebook profile of the user a message "Like and share up to London!” This is my reply to the 'Don't come in England!' British campaign (see a selection of the most successful posters in figure 3).

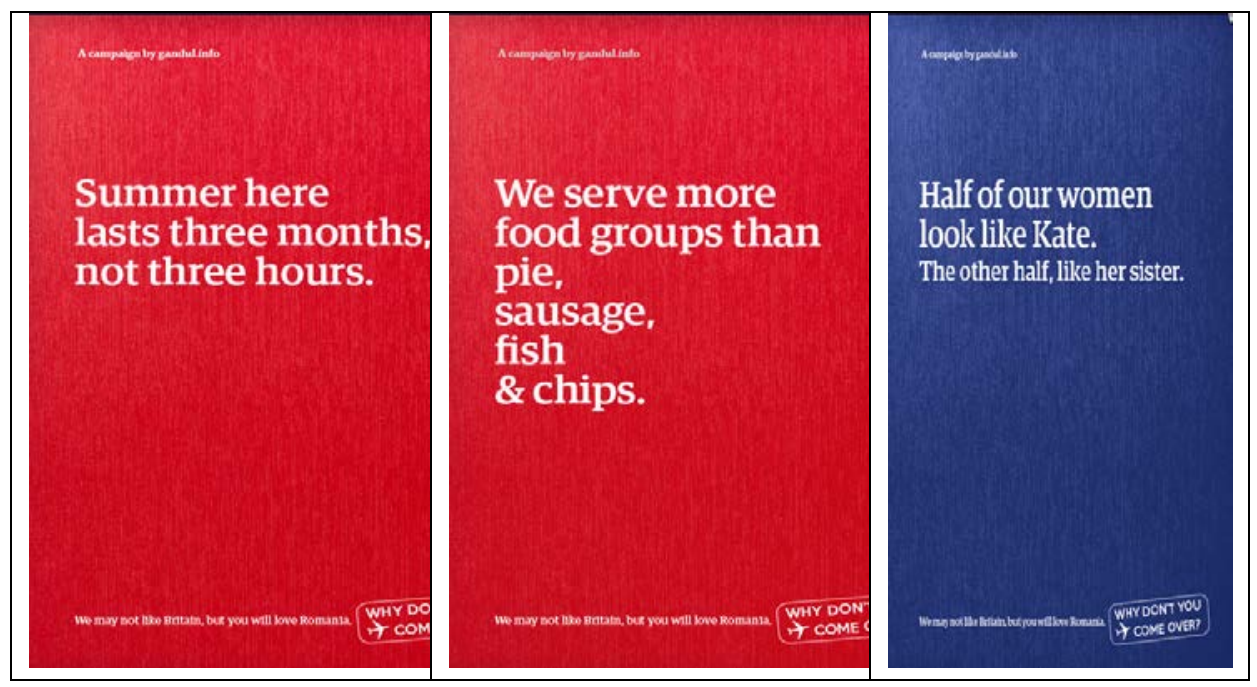




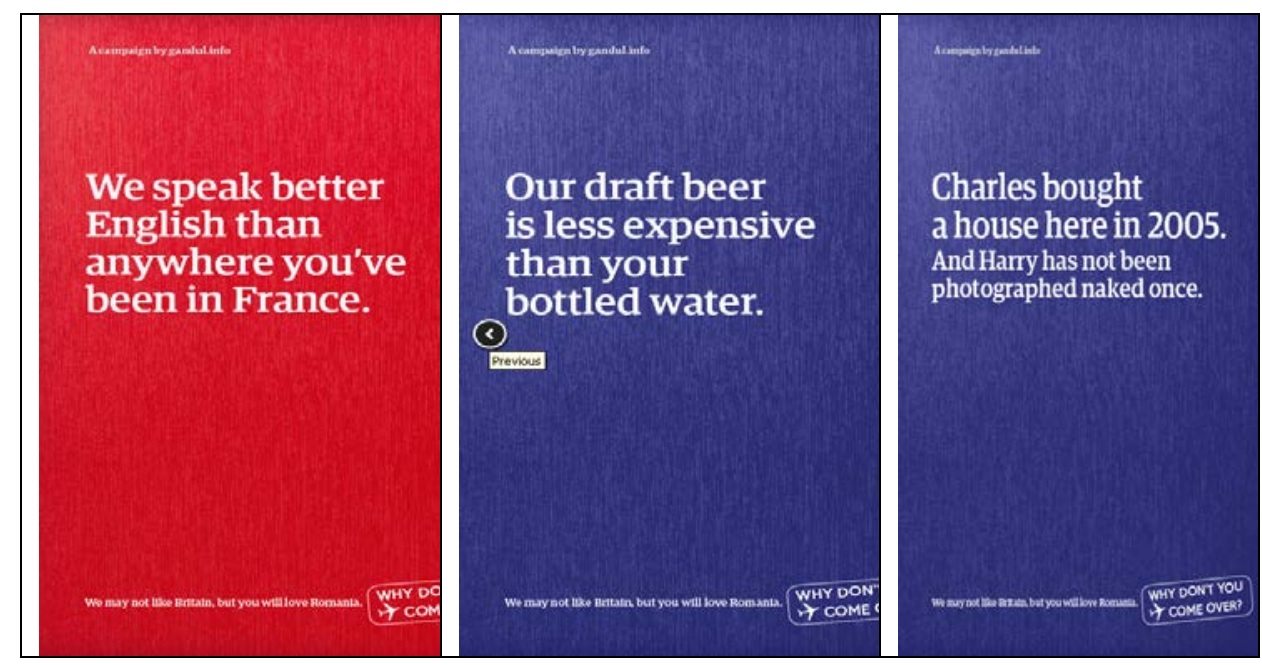

Figure 3 Successful posters in Why Don't You Come Over? campaign

Source : http://whydontyoucomeover.gandul.info/

Designed as a positive campaign (Newsom, Turk \& Kruckeberg , 2003), Why Don't You Come Over? intends, at an early stage, to identify with humor the advantages of Romania over the United Kingdom: more beautiful girls, cheaper beer and better food, the idyllic landscape also appreciated by Prince Charles. Based on the message "We may not like Britain, but you will love Romania. Why don't you come over?", in the second stage of the campaign, the British are invited to find a "couch" offered by the Romanians to spend a few days in Romania and convince themselves of the truth in the posters' messages. In addition, on the www.whydontyoucomeover.co.uk website, a special section was added where employers Romanian could offer available jobs to the British.

Readers' involvement in the campaign was beyond expectations for those who initiated it: 300 posters in the first two days. Posters designed by the readers of the Gândul newspaper enjoyed a real success within the online environment, being posted and accessed in the most popular social networks (https://www.facebook.com/ Whydontyoucomeover). The PR digital campaign can be considered successful because it has generated over 5 million views in the Romanian press (printed, online, radio, TV) and more than 100 materials in international press (see also Table 2) and received several awards and nominations both in the country and abroad.

Table 2 ‘Why Don't You Come Over?’ Campaign's Results

\begin{tabular}{|l|l|}
\hline \multicolumn{2}{|c|}{ 'Why Don't You Come Over?' Campaign's Results } \\
\hline Media impressions worldwide: 87 million & $\begin{array}{l}\text { Gandul FB Engagement Rate hit a record } \\
37 \%\end{array}$ \\
\hline Media impressions in Romania : 5.1 million & $\begin{array}{l}\text { Gandul FB “talking about this” grew by } \\
137 \%\end{array}$ \\
\hline www.whydontyoucomeover.co.uk views : 110 & Impressions on FB : 2.1 million in \\
000 & Romania alone \\
Free media exposure : euro 2 million & Gandul readership increased by 30\% \\
\hline
\end{tabular}

Source : http://www.youtube.com/watch?v=GzzB8C0ehO4 
Many representatives in the advertising industry or in the Romanian press have praised this campaign and its effects. We mention here the comment of the wellknown journalist, Cristian Tudor Popescu, who considers that this campaign has produced a "short-circuit" among peoples. "The Government of the United Kingdom, in its indolence, tells people to keep away from the Romanian....Whereas the British mock their own government. When a British says he/she voted for Tony Blair, David Cameron and Boris Johnson, but he/she has not left the UK yet because he/she does not use public transportation, it is clear that the British behave as in Caragiale: they say things that seem clear on the surface, but they mean the opposite. And they are doing it with a great sense of humor. All UK readers referred to Great Britain not as Great Britain, but Grey Britain” (Schiau, 2013). The journalist has also praised the Romanians who were involved in the campaign and have contributed decisively to its success by using their sense of humor as a tool for communication: "Imagine what reaction would our Ministry of Foreign Affairs have had: a patriotic, stiffly, like 'Come on, really, do you think that we don't have what to eat in Romania?'. Instead of this reaction, which would have been null on an international level, we have a reaction which uses an extremely efficient weapon of communication and manipulation, namely humor. Therefore, the campaign has proved to be overwhelming, viral reaching up to Huffington Post, Channel 4 or Associated Press"(Schiau, 2013).

The Romanian Internauts have continued to have a dialogue with the British even after the end of the "Do not come to England!" campaign. Although they have not had the same effect at (inter)national level, it is worth mentioning two small communication episodes: "Let's talk football!" (for the Steaua Bucharest - Chelsea match, 7 March 2013) and "Upon seeing the final elections results, Charles took the first plane to Romania" (after the victory announcement of the extremist, Farage Nige, in the European Parliament elections in UK, 2014) (Costache, 2014).

\section{A success managed by the Net Generation}

The involvement of the Net Generation's representatives in carrying out the "Why Don't You Come Over?” campaign has brought results beyond the initiators' expectations. Their participation in creating funny posters and messages and distributing them in their own networks of "N-fluence" (Tapscott, 2011) has led to record figures: over 1.500.000 impressions on Facebook, 49.000 on Twitter, more than 17.000 impressions on blogs and in comments, over 60.000 comments in the Romanian press online (Vlădescu, 2013).

This should show all those responsible in promoting Romania's image that they may involve the Net Generation's representatives in this mission at any time. Being creative and funny, they can complete all the work in the offline environment and help transforming the Romanian brand into a success story because they are interconnected and influential on the social networks to which they belong, generating content, creating communities (van Dijck, 2009) cooperating, therefore, breaking all the geographical barriers.

\section{References}

Costache, M.C. (2014), Gândul iese din nou la atac împotriva britanicilor, available at http://weinvent.ro/tag/why-dont-you-come-over/.

Curtin, P.A., Gaither, T.K. (2008), Relaţii publice internaţionale : negocierea culturii, a identitătii şi a puterii, Bucharest, Curtea Veche Publishing House. 
Dolea, A., Țărus A. (2009), Branding România. Cum (ne)promovăm imaginea de ţară, Bucharest, Curtea Veche Publishing House.

Fisher-Buttinger, C., Vallaster, Ch. (2011), Noul branding : cum să construieşti capitalul unei mărci, Iaşi, Polirom Publishing House.

Ivan, M., Kooperativa 2.0. (2013), Percepţia românilor despre brandul de ţară al României, available at http://brandstorming.blogalinitiative.ro/studiu-decaz/ce-cred-romanii-despre-romania.

Leadbeater, Ch. (2010), Noi-gândim : inovaţie de masă, nu producţie de masă, Bucharest, Publica Publishing House.

Mihai, I. (2013), Gandul si GMP Advertising raspund campaniei initiate de The Guardian impotriva imigrarii romanilor, available at http://www.iqads.ro/articol/25001/gandul-si-gmp-advertising-raspundcampaniei-initiate-de-the-guardian-impotriva.

Newsom, D., Turk J.S., Kruckeberg D. (2003), Totul despre relaţiile publice, Iaşi, Polirom Publishing House.

Nicolescu, L. (coord.) (2008), Imaginea României sub lupă ! Branding şi rebranding de ţară, Bucharest, ASE Publishing House, available at http://www.bibliotecadigitala.ase.ro/biblioteca/carte2.asp?id=508\&idb=.

Olins, W. (2006), Despre brand, Bucharest, Comunicare.ro Publishing House.

Tapscott, D. (2011), Crescuţi digital: generaţia Net ị̂i schimbă lumea, Bucharest, Publica Publishing House.

Tapscott, D., Williams, A.D. (2010), Wikinomics: cultura colaborării în masă, Bucharest, Publica Publishing House.

van Dijck, J. (2009), Users like you? Theorizing agency in user-generated content, Media, Culture \& Society, 31(1): 41-58.

van Ham, P. (2001), The rise of the brand state : The postmodern politics of image and reputation, Foreign Affairs, 80 (5), 2-6.

Future Brand. (2012), Country Brand Index 2012-13, available at http://www.futurebrand.com/images/uploads/studies/cbi/CBI_2012-Final.pdf.

Schiau, M. (2013), Cristian Tudor Popescu, despre campania "Why don’t you come over”: „Reacţia românilor e de premiul Nobel, e umor, nu băşcălie”. Cum a ajuns Hamlet faţă în faţă cu Becali, available at http://www.gandul.info/stiri/cristian-tudor-popescu-despre-campania-why-dont-you-come-over-reactia-romanilor-e-de-premiul-nobel-e-umor-nu-bascaliecum-a-ajuns-hamlet-fata-in-fata-cu-becali-video-10536437.

Vlădescu, A (2013), Campania “ Why dont’t you come over ?" continuă de astăzi în Prosport. Cu ce afişe îi aşteaptă românii pe englezii de la Chelsea, available at http://www.mediafax.ro/sport/campania-why-don-t-you-come-over-continuade-astazi-in-prosport-cu-ce-afise-ii-asteapta-romanii-pe-englezii-de-la-chelsea10630414.

Walsh, J (2013), Putting people off coming to Britain: your pictures, available at http://www.theguardian.com/uk/gallery/2013/jan/29/immigration-britainministers-gallery\#/?picture=403157094\&index=16, accessed March 15, 2014 